Models of Balance of Payments Constrained Growth 
Also by Elias Soukiazis and Pedro A. Cerqueira

INTEGRATION AND GLOBALIZATION CHALLENGES FOR DEVELOPED

AND DEVELOPING COUNTRIES (edited with $H$. Marques) 


\section{Models of Balance of Payments Constrained Growth}

History, Theory and Empirical Evidence

Edited by

Elias Soukiazis and Pedro A. Cerqueira 


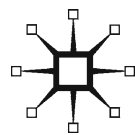

Selection, introduction and editorial matter (CElias Soukiazis and Pedro A.

Cerqueira 2012

Individual chapters @Contributors 2012

Softcover reprint of the hardcover 1st edition 2012 978-1-137-02394-0

All rights reserved. No reproduction, copy or transmission of this publication may be made without written permission.

No portion of this publication may be reproduced, copied or transmitted save with written permission or in accordance with the provisions of the Copyright, Designs and Patents Act 1988, or under the terms of any licence permitting limited copying issued by the Copyright Licensing Agency, Saffron House, 6-10 Kirby Street, London EC1N 8TS.

Any person who does any unauthorized act in relation to this publication may be liable to criminal prosecution and civil claims for damages.

The authors have asserted their rights to be identified as the authors of this work in accordance with the Copyright, Designs and Patents Act 1988.

First published 2012 by

PALGRAVE MACMILLAN

Palgrave Macmillan in the UK is an imprint of Macmillan Publishers Limited, registered in England, company number 785998, of Houndmills, Basingstoke, Hampshire RG21 6XS.

Palgrave Macmillan in the US is a division of St Martin's Press LLC, 175 Fifth Avenue, New York, NY 10010.

Palgrave Macmillan is the global academic imprint of the above companies and has companies and representatives throughout the world.

Palgrave ${ }^{\circledR}$ and Macmillan ${ }^{\circledR}$ are registered trademarks in the United States, the United Kingdom, Europe and other countries

ISBN 978-1-349-43840-2 ISBN 978-1-137-02395-7 (eBook)

This book is printed on paper suitable for recycling and made from fully managed and sustained forest sources. Logging, pulping and manufacturing processes are expected to conform to the environmental regulations of the country of origin.

A catalogue record for this book is available from the British Library.

A catalog record for this book is available from the Library of Congress.

$\begin{array}{llllllllll}10 & 9 & 8 & 7 & 6 & 5 & 4 & 3 & 2 & 1\end{array}$

$\begin{array}{llllllllll}21 & 20 & 19 & 18 & 17 & 16 & 15 & 14 & 13 & 12\end{array}$ 


\section{Contents}

List of Tables vii

List of Figures viii

Preface $x$

Notes on Contributors xii

$\begin{array}{ll}\text { Introduction } & 1\end{array}$

Elias Soukiazis and Pedro A. Cerqueira

Part I Historical Overview on the Balance of Payments Constrained Growth Debate 9

1 Balance of Payments Constrained Growth Models: History and Overview

Anthony Philip Thirlwall

2 Criticisms and Defences of the Balance of Payments Constrained Growth Model: Some Old, Some New 50 John S.L. McCombie

3 The Remarkable Durability of Thirlwall's Law Mark Setterfield

\section{Part II Alternative Models and Empirical Evidence}

4 Generalized Balance of Payments Constrained Growth and South-South Trade in Sub-Saharan Africa Alberto Bagnai, Arsène Rieber and Thi Anh-Dao Tran

5 Growth Rates Constrained by Internal and External Imbalances: A Demand-Orientated Approach

Elias Soukiazis, Pedro A, Cerqueira

and Micaela Antunes

6 Empirical Testing of the Export-led and Balance of Payments Constrained Growth: The Case of Portugal Virmantas Kvedaras 
vi Contents

\section{Part III The Convergence Issue and the Role of Exchange Rate on Balance of Payments Constrained Growth}

7 Convergence and Balance of Payments Constrained Growth: Is There a Puzzle?

Carlos Garcimartín, José Antonio Alonso and Luis Rivas

8 New Insights from a Structural Economic Dynamic Approach to Balance of Payments Constrained Growth Ricardo Azevedo Araujo

9 Structural Heterogeneity and Endogeneity of Elasticities on the Balance of Payments Constrained Growth Model 239 Fabrício José Missio and Frederico G. Jayme Jr 


\section{Tables}

1.1 Calculations of the growth rate consistent with balance of payments equilibrium, 1951-1973

1.2 Studies for individual countries 39

1.3 Studies for groups of countries 40

2.1 Changes in the composition of US total imports 73

4.1 Average growth in the last two decades in selected areas 114

4.2 Results of the unit root tests 124

4.3 Panel cointegration and pooled GFMOLS estimation 124

4.4 Thirlwall's Law in DSS low and lower middle income countries

4.5 Estimates of $\dot{Y}_{A i, B P}=\beta_{0}+\beta_{1} \dot{Y}_{A i} \quad 126$

4.6 Generalized balance of payments constrained growth in DSS (group $A$ ): whole sample, subsamples and increases

4.7 Percentage decomposition of the increase in DSS balance of payments constrained growth rate by variable and partner area between 1990-99 and 2000-08

5.1 Computation of the growth rates of domestic income, Portugal 1985-2008

5.2 Estimation of the structural growth model, Portugal 1985-2008

6.1 Integration order test results based on the ADF test 175

6.2 Summary of the misspecification tests 176

6.3 The results of testing for the co-integration rank 177

6.4 The results of testing for the acceptability of

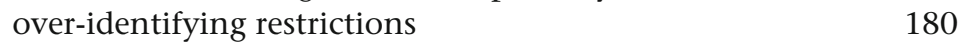

6.5 The results of estimation of unrestricted and restricted B1 specification

7.1 The $(\varepsilon / \pi)$ ratio in developed countries 194

7.2 The $(\varepsilon / \pi)$ ratio in developing countries 195

$\begin{array}{lll}7.3 & \text { Trade elasticities } & 204\end{array}$

7.4 Export elasticities 205

7.5 Import elasticities 205

7.6 Trade elasticities in France, 1960-2000 206

7.7 Import elasticities: instrumental variables 207

7.8 Export elasticities: SUR estimation 207

7.9 Import elasticities: SUR estimation 208

7.10 Steady state income per head 209

$\begin{array}{ll}7.11 \text { Contribution to income growth } & 209\end{array}$ 


\section{Figures}

1.1 The balance of payments and growth 26

2.1 Growth of output under different assumptions 65

3.1 Determination of the balance of payments constrained $\begin{array}{ll}\text { equilibrium growth rate } & 87\end{array}$

3.2 Co-determination of the actual and natural rates of growth 97

3.3 Cumulative causation and Thirlwall's Law 100

3.4 Reconciling the actual and natural rates of growth through adjustment of the income elasticity of demand for imports

3.5 Reconciling the actual and natural rates of growth through adjustment of the Verdoorn coefficient 105

4.1 The trade market shares in DSS countries

4.2 The bilateral trade balance-to-GDP ratio with developing Asia of some DSS countries

6.1 The trade deficit and the imports to exports ratio

6.2 The estimated cointegrating relationships (specification A2)

6.3 The estimated cointegrating relationships (specification B1)

7.1 The $(\varepsilon / \pi)$ ratio in developed and developing countries, Bairam (1997)

7.2 The $(\varepsilon / \pi)$ ratio in developed and developing countries, Ghani (2004)

7.3 The $(\varepsilon / \pi)$ ratio in developed and developing countries, Senhadji (1998) \& Senhadji and Montenegro (1998) 197

7.4 The $(\varepsilon / \pi)$ ratio in a sample of OECD countries 204

8.1 Growth rate of U country - Simulation 1

8.2 Growth rate of U country - Simulation 2

8.3 Growth rate of U country - Simulation 3

8.4 and 8.7 Growth rate of the U country before and after a cambial appreciation at period 50 - Simulation $1 \quad 234$

8.5 and 8.8 Growth rate of the $U$ country before and after a cambial appreciation at period 50 - Simulation 2

8.6 and 8.9 Growth rate of the U country before and after a cambial appreciation at period 50 - Simulation 3

9.1 Specialization along a "Ricardian Commodities" continuum 
9.2 Effect of variations of wages and domestic productivity 244

9.3 Specialization, balance of trade constraints and growth 246

9.4 Specialization, balance of payments constraints and growth under new $\omega \quad 247$

9.5 Specialization in innovative and Ricardian commodities 248 


\section{Preface}

This volume takes the post-Keynesian view that balance of payments can be a serious constraint to growth when external deficits are unsustainable. It also stresses that growth is demand-led and not supply-led as the neoclassical theory advocates, although supply characteristics are assumed to be important for increasing competitiveness. This volume is inspired by Thirlwall's Law and the balance of payments equilibrium growth rate, first published in 1979 as an alternative theory to the neoclassical paradigm, explaining in a more convincing manner differences in growth rates between countries. Its main message that in the long term no country can grow beyond its balance of payments equilibrium growth rate became an important policy issue. And the simple rule that an economy's actual growth rate can accurately be predicted by the ratio of export growth relatively to the income elasticity of demand for imports became a great challenge for theorists and practitioners over time. The purpose of this volume is to reconsider this law, offering a historical overview of the evolution of the balance of payments constrained growth hypothesis, explaining its remarkable resistance and updating the law to the new economic conditions. Important contributions are made by authors who believed the validity of Thirlwall's Law and worked continuously with the aim to improve, adapt and support the main ideas of the balance of payments constrained growth hypothesis.

The contributions in this volume result from the workshop held at the Faculty of Economics of the University of Coimbra in June 2011, organized to commemorate the over 30 years' existence of Thirlwall's Law. Naturally, Chapter 1 contains a historical overview of the law written by Professor Thirlwall himself, explaining the genesis and evolution of his theory over time. The two subsequent chapters analyse in a detail manner the controversy and main criticism on Thirlwall's Law providing theoretical and empirical approaches that support the validity of the balance of payments constrained growth hypothesis. The rest of the book accommodates new studies that adapt, update and improve the law showing how flexible and coherent this theory is in explaining growth performance of different countries. The volume will be of particular interest to researchers and policymakers working in the field of economic growth and international trade. 
We are grateful to all participants in the workshop on Thirlwall's Law who contributed decisively to organize this volume. We acknowledge the financial support from the research centre Group for Monetary and Financial Studies (GEMF) and the Faculty of Economics at the University of Coimbra for providing all the conditions for the realization of the workshop. In particular we wish to thank the Palgrave editor for deciding to publish this volume and providing all the assistance throughout the editing process. We also thank Alessandro Roncaglia, the editor of the SPL Quarterly Review, for his permission to reproduce some parts which first appeared in his journal. Finally, we acknowledge the effort of the contributing authors for following the editorial guidelines and tight deadlines. 


\section{Contributors}

José Antonio Alonso is Professor of Applied Economics at Universidad Complutense de Madrid. He was General Director of Economic Cooperation at the Instituto de Cooperación Iberoamericana, Vice-Chancellor at Universidad Internacional Menendez Pelayo and Director of the Instituto Complutense de Estudios Internacionales (ICEI). He is member of the Committee for Development Policy (ECOSOC, UN) and of the Consejo de Cooperación para el Desarrollo, Spain. He has specialized in economic growth and development, and international economics and has written numerous articles in academic journals such as Applied Economics, Journal of Post Keynesian Economics, European Journal of Development Research, Journal of Development Studies, Journal of International Development and CEPAL Review.

Micaela Antunes is Assistant Professor in the Department of Economics, Business and Industrial Engineering at the University of Aveiro, Portugal, and is affiliated to the Group for Monetary and Financial Studies (GEMF) research centre. She has a PhD from the Faculty of Economics, University of Coimbra. Her research interests include growth economics, regional development, international trade and applied economics. She has published in national and international journals such as the Portuguese Review of Regional Studies, Economic Modelling, Journal of International Trade and Economic Development, Journal of Post Keynesian Economics, Ekonomia and Papeles de Economia Española. She is the co-author of published working papers in European Union Studies Centre (CEUNEUROP) and Group for Monetary and Financial Studies (GEMF) in the Faculty of Economics of the University of Coimbra.

Ricardo Azevedo Araujo is Adjunct Professor in the Department of Economics at the University of Brasilia, Brazil. He is also a research associate at the Brazilian Council of Science and Technology (CNPq) and leader of the research group of Growth and Distribution. His research interests are Structural Economic Dynamics (SED) with special emphasis on growth and development, evolutionary game theory and international trade. He is the co-editor of a book on political economy and has published in journals such as Cambridge Journal of Economics, Structural Change and Economic Dynamics, Metroeconomica, Review of Political Economy and Economics Letters. 
Alberto Bagnai is Associate Professor of Economic Policy in the Department of Economics at the University "Gabriele D'Annunzio", Chieti, Italy, and research fellow at the Centre for Research in Economics Applied to Globalisation (CREAM), University of Rouen. His main research and teaching interests are in the areas of emerging market economies and applied international macroeconomics. His recent work deals with the sustainability of the government and the current account deficits, the twin deficits phenomenon, international capital mobility and exportled growth models. His published research has appeared in Review of the World Economy, Economic Modelling, Open Economies Review, China Economic Review and Applied Economics, as well as in other international reviews and in chapters of books.

Pedro A. Cerqueira is Assistant Professor in the Faculty of Economics at the University of Coimbra, Portugal. He holds a PhD in Economics from the European Institute, Florence, Italy, and a Master's in Monetary and Financial Economics from ISEG, Technical University of Lisbon, Portugal. His research interests include the economics of European integration, business cycles and open macroeconomics. He is a member of the research centre Group for Monetary and Financial Studies (GEMF) of the University of Coimbra. He is the co-editor of two books on integration and globalization and has published in journals such as Kyklos, Economics Letters, Open Economies Review and Economic Modelling.

Carlos Garcimartín is Professor of Economics at Universidad Rey Juan Carlos, Madrid, Spain. He has also been affiliated with the Universities of Salamanca and Complutense de Madrid. He has worked for the Spanish Ministry of Finance and the Spanish Tax Agency. His main research topics are public economics, international economics and development economics. He has been involved in national and international research projects and has worked as consultant for some international organizations. He has published articles in prestigious international journals such as the Journal of Post Keynesian Economics, Review of Income and Wealth, the Annals of Regional Science, Journal of International Development and CEPAL Review.

Frederico G. Jayme Jr. is Professor of Economics and Director of the Graduate Studies in Economics at Federal University of Minas Gerais, Brazil. His research interests include applied economics and especially on growth and development, international finance, regional economics and macroeconomics. He has extensively published in these areas, being also the co-editor of three books. He has also published in journals such as 
the Journal of Post Keynesian Economics, World Development, CEPAL Review and Brazilian Journal of Political Economy, among others. He has also published chapters in books and a great number of working papers.

Virmantas Kvedaras is Associate Professor in the Faculty of Mathematics and Informatics at the Vilnius University, Lithuania. His research interests are in applied and financial econometrics. He is an associate editor of the Bank of Lithuania's journal entitled Monetary Studies and has published papers in such journals as Applied Economics Letters, Economics Letters, Open Economies Review and Oxford Bulletin of Economics and Statistics.

John S. L. McCombie is Professor of Regional and Applied Economics and Director of the Cambridge Centre for Economic and Public Policy, Department of Land Economy at the University of Cambridge. He is also Fellow and Director of Studies in Economics, Downing College, Cambridge. He received his PhD from the University of Cambridge and has been a member of the Department of Economics at the University of Hull and the University of Melbourne, Australia. His areas of research include the causes of regional and national growth rate disparities, a critique of the aggregate production function and economic methodology. He is a co-editor of the journal Spatial Economic Analysis and is a fellow of the Regional Studies Association. He has published over one hundred articles in journals and chapters in books. Journals in which he has published include the Economic Journal, Oxford Economic Papers, the Manchester School, Cambridge Journal of Economics and the Journal of Post Keynesian Economics. He has co-authored and co-edited 12 books including Essays on Balance of Payments Constrained Growth (2004), Unemployment: Past and Present (2008) and Missing Links in the Unemployment Relationship (2009).

Fabricio José Missio is Associate Professor of Economics at the University of Mato Grosso do Sul, in Centre-West of Brazil. He is a member of the Brazilian Keynesian Association (AKB). His research interests are on macroeconomic policy, technological change and Growth Economics. He has published in Brazilian Economic journals such as Brazilian Journal of Political Economy, Economia e Sociedade and has also a number of working papers in progress.

Arsène Rieber is Associate Professor in Economics at the University of Rouen and Head of the Centre for Research in Economics Applied to 
Globalisation (CREAM), University of Rouen. His main fields of interest are the macroeconomic issues of globalization and development strategies. His recent research focuses on international demand spillovers in South-South trade, export performance and South-South integration, and export-led growth models.

Luis Rivas is Associate Professor at Universidad Pontificia de Salamanca and IE University. He has been a researcher at several universities. He has been involved in national and international research projects and has published articles on balance of payments constrained growth in the Journal of Post Keynesian Economics. His main research topics are economic growth, international trade and fiscal policy.

Mark Setterfield is Maloney Family Distinguished Professor of Economics in the Department of Economics at Trinity College, Hartford, Connecticut. He is also an associate member of the Cambridge Centre for Economic and Public Policy at the University of Cambridge, a senior research associate at the International Economic Policy Institute, Laurentian University, Canada and a member of the Centre d'Économie de l'Université Paris Nord (CEPN) at l'Université Paris XIII (France). His main research interests are macro dynamics (with a particular focus on the development and application of concepts of path dependence) and Post-Keynesian economics. He is the author of Rapid Growth and Relative Decline: Modelling Macroeconomic Dynamics with Hysteresis (1997), the editor or co-editor of six volumes of essays, and he has published in numerous journals including the Cambridge Journal of Economics, Journal of Post Keynesian Economics, European Economic Review, Review of Political Economy, Journal of Economic Issues and the Manchester School.

Elias Soukiazis is Associate Professor in the Faculty of Economics at the University of Coimbra, Portugal. He is a member of the Advisory Committee of the European Economics and Finance Society (EEFS) and Board Member of the International Network for Economic Research (INFER). He is also a member of the research centre Group for Monetary and Financial Studies (GEMF) of the University of Coimbra. His research interests are in Applied Economics and especially on growth and development, European economics, international trade, human and health capital as well as regional economics. He is the co-editor of two books on integration and globalization and has published in journals such as Journal of Policy Modelling, Journal of Post Keynesian Economics, Review of Development Economics, Economic Modelling, International Trade Journal, Journal 
of International Trade and Economic Development, Tourism Economics and Portuguese Economic Journal. He has also published chapters in text books and a number of working papers.

Anthony Philip Thirlwall is Professor of Applied Economics at the University of Kent, UK, and has held visiting positions in other universities, including Princeton, Cambridge, Melbourne and La Trobe. He is the author of several books in the field of growth and development, including Economic Growth and the Balance of Payments Constraint (with J. S. L. McCombie) and his best-selling textbook, Economics of Development: Theory and Evidence.

Thi Anh-Dao Tran is Associate Professor in Economics at the University of Rouen and Research Fellow at the Centre for Research in Economics Applied to Globalization (CREAM), University of Rouen. She is seconded to the French Institute of Research for Development (IRD) in Hanoi, Vietnam. Her main fields of interest are the macroeconomic issues of international integration and development, with a focus on the emerging economies of East and Southeast Asia. She has published in various journals such as Asia-Pacific Journal of Accounting and Economics, Comparative Economic Studies and Journal of Social and Policy Sciences. 